\title{
A MULTI-DIMENSIONAL FRAMEWORK TO ASSIST IN THE DESIGN OF SUCCESSFUL SHARED SERVICES CENTRES
}

\author{
Mark Borman \\ The University of Sydney \\ Email: mark.borman@sydney.edu.au
}

\begin{abstract}
Organisations are increasingly looking to realise the benefits of shared services yet there is limited guidance available as to the best way to proceed. A multi-dimensional framework is presented that considers the service provided, the design of the shared services centre and the organisational context it sits within. The specific dimensions identified are task, strategy, structure, management processes, individual skills, information technology, environmental conditions, history and organisational resources. Case studies are then used to determine what specific attributes from each dimension are associated with success. It is concluded that there appears to be broadly standard patterns of attributes across the dimensions that differentiate between successful, moderately successful and limited success shared services centres (SSCs).
\end{abstract}

Keywords: Shared services, Alignment, Information Technology, Success, Attributes

\section{INTRODUCTION}

Why look at shared services? Primarily because while they have been promoted as an emerging area offering enormous potential, limited guidance is available to organisations. Bergeron (2003) suggests that approximately $50 \%$ of fortune 500 companies have established some form of shared services operation. He also provides the example of Bristol Myers Squib's global business service unit realising annual savings of US\$1.5billion. Rayner (2006) similarly highlights the cost savings achieved by Reuters while Cecil (2000) gives the example of Ford being able to reduce its finance department staffing from 14,000 to 3,000 through the introduction of shared services. Longwood et al. (2007) however suggest that success is not guaranteed and that many organisations will fail to achieve their objectives. One recent example was the government of Western Australia which sought to merge finance and payroll processing services across multiple departments. The project, started in 2007, and was estimated to cost AU\$82 million and deliver annual savings of AU\$57 million. However by the time of termination AU\$401 million had been spent (Kerr 2011).

Shared services are of specific interest from an information systems (IS) perspective because it has increasingly been recognised by researchers in the field that there is merit in looking beyond the IS itself to examine the functions and activities that are enabled by it - see for example Willcocks et al. (2007), MacGregor et al. (2009), Roseman et al. (2009), Leonardi et al. (2008) and Kerr et al. (2010). Shared services would appear to represent such an activity with authors such as Hagel III et al. (2001) arguing that IS will underpin their delivery. Indeed the shared services in Western Australia referred to above was founded upon the establishment of a common Enterprise Resource Planning (ERP) system (Kerr 2011). Yet while a significant body of research has been constructed regarding other modes of organising business activities that rely and build upon IS - see for example Borman (2006) with regard to business process outsourcing - relatively little attention has been paid to shared services. The majority of the available advice to organisations is currently 
provided by consultants - for example Schulman et al. (1999) or Quinn et al. (2000) - and is often anecdotal in nature. While an academic literature is slowly emerging, to date it has often been unstructured with many of the claims or assertions unsupported by empirical evidence - see for example publications by Shah (1998) and Kreklow et al. (2007). There are notable exceptions - for example Janssen et al. (2006) - but even here the research has often been restricted to a relatively narrow domain - in that instance to the public sector. The objective of the current paper is to develop a more comprehensive analysis of shared services. In particular the research examines a range of sectors through the lens of a multi-dimensional framework to determine what attributes might be commonly associated with successful shared services. As such it should provide enhanced guidance for organisations embarking on shared services initiatives.

The remainder of the paper comprises two sections. The first outlines a set of dimensions that can be used to analyse shared services centres (SSCs). The second examines shared services in 11 organisations in Australia through the lens of those dimensions seeking to determine if there is a prevalent pattern or alignment of attributes across them associated with success. Before progressing however it is useful to define what shared services are. Many definitions with slightly different nuances exist - see Schulz et al. (2010) for an extensive review. Schulman et al. (1999) for example define them as

"The concentration of company resources performing like activities, typically spread across the organization, in order to service multiple internal partners at lower cost and with higher service levels, with the common goal of delighting external customers and enhancing corporate value" (p9)

while Bergeron (2003) suggests

"Shared services is a collaborative strategy in which a subset of existing business functions are concentrated into a new semi-autonomous business unit that has a management structure designed to promote efficiency, value generation, costs savings and improved service for the internal customers of the parent corporation, like a business competing in the open market" (p3)

The essence though is that a shared service is one where the provision of a back office service such as payroll processing, accounts payable or foundational IT services - is consolidated within a single area of an organization (Longwood et al. 2007; Quinn et al. 2000; Ulbrich 2006).

\section{SHARED SERVICES: DIMENSIONS, ALIGNMENT AND PERFORMANCE}

The overarching objective of this paper is to determine if there are one or more alignments of attributes, across a series of dimensions, associated with successful SSCs. The following section will first discuss prior research into alignment and its association with success before outlining the specific conceptualisation adopted here. It will then identify a set of dimensions across which an alignment of attributes associated with successful SSCs can be sought. Finally the view of how success will be assessed is presented.

Research examining alignment has often struggled because it has failed to clearly define what is meant by alignment (see Chan and Reich, 2007). Alignment has been described in a variety of ways - for example as fit (White 1986), support (Luftman et al. 1993) or configuration (Mintzberg et al. 1999). Perhaps the most comprehensive consideration of alignment is that of Venkatraman (1989) who identified, and defined, six alternative definitions - moderation, mediation, matching, gestalts, profile deviation and covariation. Mediation, moderation and matching look only for a fit between two variables - an approach which Child (1975) suggests can lead to potential contradictions. Of the remaining multivariate approaches, profile deviation has been criticised for its focus on ideal types which are not generally observable in reality (Lee et al. 2004; Weber 1978). The gestalt approach 
however is well accepted in the IS literature (Drazin et al. 1985; Lee et al. 2004; Pollalis 2003) and has been applied previously to outsourcing (Kern 1997). At its core, according to Miller (1982), is a focus on the whole, describing relationships between a range of elements, to identify unique forms or gestalts rather than looking at simple associations between a restricted set of variables. While avoiding issues of causality (Hrebiniak 1981), a focus on gestalts recognises that it is possible for a variety of organisational forms, or configurations, to emerge and flourish within a particular environment (Hannan et al. 1977; Katz et al. 1966) thus avoiding tendencies towards prescription and the best solution. As compared to the remaining definition of alignment - covariation Venkatraman (1989) suggested that the two are very similar differing "only in relation to the degree of specification of the functional form" (p436) with gestalts viewed "as products of cluster analysis .. whereas covariation is modeled as factor analysis" (p436). It is proposed here that aspects of the gestalt and covariation approaches can potentially be usefully combined. The principles of covariation can be used to identify relevant attributes for each proposed alignment dimension, with a gestalt approach then being used to determine whether organisations can be grouped based upon variations in those attributes.

With regard to identifying the specific dimensions to be aligned, the focus is on the requirements for a particular function - shared services - to be successful. A review of the literature suggests that a number of authors have considered the alignment requirements between functions within an organisation - for example Hooper et al. (2007) with regard to IT and marketing - or between one function and the broader business operation - Chan et al. (1997), for example, consider the relationship between IT and business strategy. However there appears to be scant literature examining the alignment requirements for the effective operation of specific single function or activity. Exceptions are Hall (1962) and Van de Ven et al. (1974) but these have a narrow focus on the relationship between the nature of a task and one other factor - the degree of bureaucratisation in the first instance and the work-unit structure in the second. By far the most extensive and developed body of literature in the area relates to the examination of alignment at the organisation level. Numerous authors have suggested that the complexity of the modern organization needs to be understood from the perspective of multiple dimensions with its success being determined by the congruence, fit or alignment amongst them (Galbraith 2002; Henderson et al. 1993; Leavitt 1965; Nadler et al. 1997; Scott-Morton 1991). Leavitt (1965) for example emphasised that the dimensions "are highly interdependent .. so that change in any one usually results in compensatory (or retaliatory) change in others" ( $\mathrm{p} 1145)$. This literature was therefore used as the starting point for indentifying a set of functional alignment dimensions.

The actual approach adopted is a synthesis of the frameworks developed by Scott-Morton (1991) and Nadler et al. (1997). Chan et al. (2007) in their comprehensive review of the organisational design literature trace many alignment models back to Scott-Morton (1991) which itself draws significantly from an earlier work by Leavitt (1965). However Scott-Morton (1991) is not without its own limitations. While recognising that the organisation cannot be considered in isolation but needs to be positioned within an environment he did not seek to examine that environment in detail. Nadler et al. (1997) suggested that the "givens or setting within which the organisation must operate" (p29) was made up of three components: environmental conditions, organisational resources and history. There are similarities between the Nadler et al. (1997) categories and those of other, well respected, authors, such as Porter (1991) and Mintzberg (1998), who have sought to examine the influence of an organisation's environment on its performance. However the former was chosen as it appears to more directly capture both the range of influences and their essential essence. For example, the components allow for a broader consideration of influences than the five forces approach of Porter (1991) and resources and history more clearly encapsulate that it is past decisions and the ability to utilise an organisation's resources that is of interest than do the more indirect age, size and power constructs of Mintzberg (1998). 
One further addition was made to the Scott-Morton (1991) framework. Without explanation or justification, Scott-Morton (1991), and the authors who subsequently built upon and developed his work, omitted consideration of what Leavitt (1965) described as the "industrial organizations' raisons d'être" (p1144) - the specifics of the task it has been designed to undertake. As outlined in March (1965) there are many different types of tasks with varying characteristics that will influence what constitutes an appropriate organisational design. Task was therefore added as a dimension.

The complete framework used here thus includes the following dimensions:

- $\quad$ Task

- Strategy

- Structure

- Management processes

- Individual skills

- Information technology

- Environmental conditions

- History

- Organisational resources

A problem with many of these dimensions is that they have been left partially or wholly undefined. Below the work of leading authors who have considered organisational design is discussed as it relates to each dimension. An initial outline of each dimension, mapped from the level of an organization to that of a function - shared services - is then provided. Clearly alternative perspectives are possible - there is considerable debate regarding many of the dimensions - see Faulkner (2002) for a comprehensive review of the literature relating to strategy for example - but the authors cited are recognised as pre-eminent in their fields. The objective is not a complete review of the literature but to establish a starting point relevant to the objectives of the research (Walsham 1993).

\section{Task}

Porter (1991) recognised that within an organisation there will be many different types of activity often with fundamentally different characteristics. He classified activities though on the basis of what function they fulfill, for example inbound logistics, rather than on the basis of those characteristics. Mintzberg (1998) however did look at the nature of the work itself categorising it on the basis of the proportion of the total activity or process included and the degree to which it is routine with pre-specified actions requiring limited discretion.

\section{Application to shared services:}

The extent to which the activities provided by the SSC are routine and provided in their entirety.

\section{Strategy}

Chandler (1962) defined strategy "as the determination of the basic long term goals and objectives of an enterprise and the allocation of resources necessary for carrying out these goals" (p13). Similar general definitions have been provided by other authors such as Andrews (1971) and Venkatraman (1985). Porter (1985) was more specific suggesting three alternative strategies differentiation, cost leadership and focus - that organisations should work towards.

\section{Application to shared services:}

The long term goals of the SSC, with respect to differentiation, cost leadership and focus, and approaches to their realisation. 


\section{Structure}

Chandler (1962) defined structure as "the design of organization through which the enterprise is administered' (p14). Etzioni (1965) provided more detail suggesting it is the "means used by an organization to elicit the performances it needs and to check whether the quantities and qualities of such performances are in accord with organizational specifications" (p650).

\section{Application to shared services:}

The mechanisms by which the performance of the SSC is enabled and monitored.

\section{Management processes}

According to Scott-Morton (1991) management processes relate to the means through which the general employee body within an organization are directed and controlled (p12). The domain of influence of management processes therefore differs from that of structure - though the two ideally reinforce one another. Structure focuses in broad terms on establishing hierarchies, rules policies and procedures. Management processes relate to the operational requirements and mechanisms for directing specific individuals or groups. Mintzberg (1998) suggested that consideration should also be given to how relationships - particularly boundary crossing ones - are developed and maintained.

\section{Application to shared services:}

The means through which management direct and supervise SSC employees and establish and maintain relationships between the SSC and the broader organisation.

\section{Individual skills}

Rather than specific skills Scott-Morton (1991) and others, such as Taylor (1911), Davis et al. (1955) and Dunphy et al. (1998), have focused on job design and the skills required of employees especially with regard to the potential for deskilling, up-skilling or multi-skilling.

\section{Application to shared services:}

The current and required skill base of the SSC.

\section{Information technology}

Scott-Morton (1991) defined information technology in terms of six components - hardware, software, networks, workstations, robotics and smart chips. Perhaps more useful as a guide, than such a focus on specific artifacts, is the work of authors such as Weill et al. (1996), who examine the contribution of technology to organisational success from the perspective of overarching design principles - particularly with regard to the significance attached to technology and the extent to which that technology has been designed with the purpose of serving as an underpinning infrastructure.

\section{Application to shared services:}

The design and contribution of the IT used by the SSC.

\section{Environmental conditions}

Nadler et al. (1997) proposed that consideration of an organisation's environment should cover "people, other organizations, social and economic forces, and legal constraints.. markets (clients or customers), suppliers, governmental and regulatory bodies, technological and economic conditions, labour unions, competitors, financial institutions and special interest groups" (p29). Mintzberg 
(1998), and others such as Porter (1991), though suggest that the focus should not be on describing the different elements of an environment but rather on understanding the forces that influence its attractiveness. Porter (1991) primarily considered how threatening an environment was while Mintzberg (1998) also focused on the variety present (more variety restricting the degree of standardisation that could be introduced into an organisation's operations).

\section{Application to shared services:}

The variety and hostility faced by the SSC.

\section{History}

Porter (1991) recognised that "firms inherit positions that constrain and shape their choices" (p104) but did not provide any details. Nadler et al. (1997) provided more guidance suggesting that the decisions an organisation took in its past with regard to factors such as focus, behaviour and culture shape the way it functions in the present.

\section{Application to shared services:}

The organizational modus operandi inherited by the SSC.

\section{Organisational resources}

Porter (1991) suggested that a firm accumulates strengths in certain resources and skills - and potential weaknesses in others - which together shape and constrain what it can achieve. Nadler et al. (1997) added further granularity by differentiating between tangible - employees, technology, capital - and intangible - reputation, morale - resources.

\section{Application to shared services:}

The organisation's tangible and intangible resources and skills whose presence or absence are seen as key influences on the effectiveness of the SSC.

In addition to identifying and defining the dimensions of interest, the research, with its focus on the contribution of alignment to success, requires that what represents success be specified. There has been a long debate in the IS field about appropriate measures of success and many alternatives suggested (DeLone et al. 1992). Seddon et al. (1999) and Stockdale et al. (2006) have questioned though whether the most commonly used deterministic approaches can effectively capture the concept of success - especially across multiple varied contexts. With the objective of investigating alignment for shared services in general a heterogeneous sample of cases was sought, as outlined in the methodology section below, making it difficult to select objective measures that would be equally applicable to all. Consequently a broader, more subjective, approach - informed by the work of Walsham (1993) and Farbey et al. (1999) - was adopted which allowed interviewees to make, and explain, an assessment based upon the criteria that were important in their context. This has been termed perceived success. Such an approach has previously been seen as appropriate for ongoing relationship based settings (Dibbern et al. 2004; Domberger et al. 2000; Willcocks et al. 2007) - of which shared services represent a prime example. Success was assessed from the perspective of the SSC not the users of its services. It is recognised that users might have a different viewpoint (Walsham 1993) but the focus of the research was on the SSC and whether it attained the goals the organisation had set it. 


\section{METHODOLOGY}

Given that little research has been conducted on shared services, a case study based approach was deemed to be appropriate (Benbasat et al. 1987; Strauss et al. 1990). A multi-case approach was taken for the study with a primary emphasis on maximising the likely generalisability of the results since the ultimate objective was to increase understanding of the relationship between SSC design and performance (Herriott et al. 1983; Yin 1981). As such the focus was on the breadth, rather than the depth, of coverage and the number of interviews conducted within each organisation was restricted. Given the research area of interest was the design of shared services the focus was on the SSC not their clients or customers. A total of 11 SSCs were interviewed across Australia - which is in line with the median number of sites included in multi-site studies as reported by Herriott et al. (1983) - in a range of sectors including Government, Power, Transport, Building, Mining and Telecommunications. Australia was chosen as it has been recognised as an early adopter with regard to shared services (Longwood et al. 2007). Interviews were between one and two hours in duration and a semi-structured interview protocol was followed to introduce a degree of commonality while minimising the potential for overlooking the unique aspects of each context (Firestone et al. 1982). Details of interviewees and their SSCs are provided in Table 1 and the foundation protocol in Appendix 1.

\begin{tabular}{|c|c|c|c|c|}
\hline $\begin{array}{c}\text { Shared } \\
\text { service } \\
\text { centre } \\
\text { (SSC) }\end{array}$ & Sector & Age of SSC & $\begin{array}{c}\text { No. of } \\
\text { employees } \\
\text { - full time } \\
\text { equivalent }\end{array}$ & Interviewees \\
\hline SSC1 & Government & 6 years & $\approx 700$ & Managing Director (MD) \\
\hline SSC2 & Government & 9 years & $\approx 550$ & $\begin{array}{l}\text { Director Corporate Services (DCS), } \\
\text { General Manager Corporate Services } \\
(\text { GMCS) }\end{array}$ \\
\hline SSC3 & Government & 12 years & $\approx 540$ & $\begin{array}{l}\text { General Manager (GM), Finance } \\
\text { Director (FD) }\end{array}$ \\
\hline SSC4 & Construction & $\approx 12$ years & $\approx 80$ & Manager Shared Services (MSS) \\
\hline SSC5 & Energy & 6 years & $\approx 120$ & $\begin{array}{l}\text { Manager Financial Services (MFS), } \\
\text { Group Executive Shared Services } \\
\text { (GESS) }\end{array}$ \\
\hline SSC6 & Energy & 4 years & $\approx 500$ & $\begin{array}{l}\text { General Manager (GM), Manager Client } \\
\text { Services (MCS) }\end{array}$ \\
\hline SSC7 & Mining & $\approx 7$ years & $\approx 500$ & $\begin{array}{l}\text { General Manager Shared Services } \\
\text { (GMSS) }\end{array}$ \\
\hline SSC8 & Government & 6 years & $\approx 700$ & $\begin{array}{l}\text { General Manager (GM), Project Director } \\
\text { (PD) }\end{array}$ \\
\hline SSC9 & Logistics & $\approx 8$ years & $\approx 270$ & $\begin{array}{l}\text { General Manager (GM), Manager } \\
\text { Service Delivery (MSD) }\end{array}$ \\
\hline SSC10 & Telecommunications & $\approx 20$ years & $\approx 700$ & $\begin{array}{l}\text { General Manager (GM), Finance } \\
\text { Director (FD) }\end{array}$ \\
\hline SSC11 & Government & $\approx 6$ years & $\approx 250$ & $\begin{array}{l}\text { General Manager (GM), Executive } \\
\text { Manager (EM) }\end{array}$ \\
\hline
\end{tabular}

Table 1: Interviewee details 
With regard to analysis, data was first reviewed and coded in terms of its relationship to the dimensions identified - an approach in accord with the recommendations of Miles et al. (1994) and Yin (1981) who suggest organising data "around the substantial topics of the case study" (Yin 1981, p60). At the same time a case comparison approach underlay the analysis (Yin 1981). The resultant data display tables represent a crucial link in the chain of evidence between the raw data and the subsequent analysis and development of conclusions (Yin 1979). Given the research focus was on determining whether there are one or more alignments of attributes associated with success it was felt to be inappropriate to develop propositions relating to the contribution of the dimensions individually (Hathaway 1995). Consequently, at a holistic level the following propositions were developed:

\section{Proposition 1: $\quad$ There exists at least one alignment of attributes across the dimensions identified that is associated with successful shared services}

Proposition 2: Deviations from that alignment will be associated with less successful shared services

\section{RESULTS}

As outlined in the methodology the results of the case study interviews were codified and collated into data display tables - see Appendix 2 for a summary. Table 2 maps the themes identified in the interviews to the definitions of the dimensions outlined previously while Table 3 maps attributes to each SSC. The themes are elaborated upon below.

\section{Success}

Originally it was intended to have a simple successful/unsuccessful dichotomy. However the interviews made it clear that there were a number of SSCs that classified themselves as partially successful or "on the way but not there yet". As such a three point scale was introduced. Three SSCs assessed themselves as performing on the bottom point of the scale (Limited success), three at the middle (Moderate success) and five at the top (Successful). The explanations behind the assessments can be summarized as:

Limited success Very little if any benefits realised and significant questioning of the merits of shared services and whether to continue

Moderate success Some benefits starting to be realised but a perception that there is still work to be done in convincing the organisation of the merits of shared services and the bulk of the benefits are further down the line

Successful Significant benefits realized

Table 4 summarises the perception of each SSC regarding its success together with illustrations of the explanations given in support. There did not appear to be any obvious association between the age, sector or size of a SSC and success. Those SSCs perceived as being successful for example operated in five different sectors, ranged in age from 6 to 20 years and employed from 80 to 700 FTE employees. 


\begin{tabular}{|c|c|c|}
\hline Dimension & $\begin{array}{l}\text { Components } \\
\text { of definition }\end{array}$ & Interviewee themes \\
\hline \multirow[t]{3}{*}{ Success } & \multirow[t]{3}{*}{ Perception } & Successful \\
\hline & & Moderate \\
\hline & & Limited \\
\hline \multirow[t]{4}{*}{ Task } & \multirow[t]{2}{*}{ Routine } & Transaction processing \\
\hline & & NOT expert services \\
\hline & \multirow[t]{2}{*}{ Complete (entirety) } & Provided/Managed end to end \\
\hline & & Multiple service lines \\
\hline \multirow[t]{2}{*}{ Strategy } & Long term goal & Economies of scale \\
\hline & Approaches to realisation & Process improvement \\
\hline \multirow[t]{5}{*}{ Structure } & \multirow[t]{3}{*}{ Performance enablement } & Compulsory use \\
\hline & & Standardised processes \\
\hline & & User pays \\
\hline & \multirow[t]{2}{*}{ Performance monitoring } & $\begin{array}{l}\text { Accountable for performance } \\
\text { improvement }\end{array}$ \\
\hline & & External benchmarking of performance \\
\hline \multirow[t]{7}{*}{ Management processes } & \multirow[t]{4}{*}{ Direction } & Leadership focus \\
\hline & & Process \& work level understanding \\
\hline & & Large group management expertise \\
\hline & & Transparency \\
\hline & Control & Measurement emphasis \\
\hline & \multirow{2}{*}{$\begin{array}{l}\text { Relationship establishment } \\
\text { \& maintenance }\end{array}$} & Good relationship with the business \\
\hline & & Exit path for staff into business \\
\hline \multirow[t]{2}{*}{ Individual skills } & Skill base in place & NOT too low a skill base \\
\hline & Skill base required & Enable flexibility \\
\hline \multirow[t]{2}{*}{ Information technology } & Contribution of IT & IT as foundation \\
\hline & Design of IT & Standard IT \\
\hline \multirow{3}{*}{$\begin{array}{l}\text { Environmental } \\
\text { conditions }\end{array}$} & Variety & Standard operating model \\
\hline & \multirow[t]{2}{*}{ Hostility } & NO cost cutting backdrop \\
\hline & & NOT demanding immediate results \\
\hline \multirow[t]{2}{*}{ History } & \multirow{2}{*}{$\begin{array}{l}\text { Organisational ethos } \\
\text { inherited }\end{array}$} & Strong centre \\
\hline & & Core business focus \\
\hline \multirow[t]{3}{*}{ Organisational resources } & \multirow[t]{2}{*}{ Tangible resources } & Available capital investment funds \\
\hline & & IT in situ beforehand \\
\hline & Intangible resources & Senior management commitment \\
\hline
\end{tabular}

Table 2: mapping of dimension definitions to interview theme 


\begin{tabular}{|c|c|c|c|c|c|c|c|c|c|c|c|c|c|}
\hline \multirow[t]{2}{*}{$\begin{array}{l}\text { Classific } \\
\text {-ation }\end{array}$} & \multirow[t]{2}{*}{ Dimension } & \multirow[t]{2}{*}{ Element/attribute } & \multicolumn{3}{|c|}{$\begin{array}{c}\text { Limited } \\
\text { success (3) }\end{array}$} & \multicolumn{3}{|c|}{$\begin{array}{c}\text { Moderate } \\
\text { success (3) }\end{array}$} & \multicolumn{5}{|c|}{ Successful (5) } \\
\hline & & & $\begin{array}{l}\mathbf{S} \\
\mathbf{S} \\
\mathbf{C} \\
\mathbf{3}\end{array}$ & $\begin{array}{l}S \\
S \\
C \\
6\end{array}$ & $\begin{array}{c}S \\
S \\
C \\
11\end{array}$ & $\begin{array}{l}\mathbf{S} \\
\mathbf{S} \\
\mathbf{C} \\
\mathbf{1}\end{array}$ & $\begin{array}{l}S \\
S \\
C \\
8\end{array}$ & $\begin{array}{l}\mathrm{S} \\
\mathbf{S} \\
\mathrm{C} \\
\mathbf{9}\end{array}$ & $\begin{array}{l}\mathbf{S} \\
\mathbf{S} \\
\mathbf{C} \\
\mathbf{2}\end{array}$ & $\begin{array}{l}S \\
S \\
C \\
4\end{array}$ & $\begin{array}{l}S \\
S \\
C \\
5\end{array}$ & $\begin{array}{l}\mathrm{S} \\
\mathbf{S} \\
\mathrm{C} \\
7\end{array}$ & $\begin{array}{l}\mathbf{S} \\
\mathbf{S} \\
\mathbf{C} \\
\mathbf{1} \\
\mathbf{0}\end{array}$ \\
\hline \multirow{7}{*}{$\begin{array}{l}\text { Fundame } \\
\text { ntals }\end{array}$} & Strategy & Economies of scale & 1 & 1 & 1 & 1 & 1 & 1 & 1 & 1 & 1 & 1 & 1 \\
\hline & Task & Transaction processing & 1 & 1 & 1 & 1 & 1 & 1 & 1 & 1 & 1 & 1 & 1 \\
\hline & Technology & IT as foundation & 1 & 1 & 1 & 1 & 1 & 1 & 1 & 1 & 1 & 1 & 1 \\
\hline & Task & Multiple service lines & 1 & 1 & 1 & 1 & 1 & 1 & 1 & 1 & 1 & 1 & 1 \\
\hline & Technology & Standard IT & 1 & & 1 & & 1 & 1 & 1 & 1 & 1 & 1 & 1 \\
\hline & Resources & $\begin{array}{l}\text { Available capital } \\
\text { investment funds }\end{array}$ & 1 & 1 & & 1 & 1 & 1 & 1 & 1 & 1 & 1 & \\
\hline & History & Core business focus & & 1 & 1 & & 1 & 1 & 1 & 1 & & 1 & 1 \\
\hline \multirow{15}{*}{$\begin{array}{l}\text { Different } \\
\text { iators } \\
\text { between } \\
\text { successf } \\
\text { ul or } \\
\text { moderate } \\
\text { success } \\
\text { and } \\
\text { limited } \\
\text { success }\end{array}$} & Strategy & Process improvement & & & & 1 & 1 & 1 & 1 & 1 & 1 & 1 & 1 \\
\hline & Environment & $\begin{array}{l}\text { NOT demanding } \\
\text { immediate results }\end{array}$ & & & & 1 & 1 & 1 & 1 & 1 & 1 & 1 & 1 \\
\hline & Structure & Compulsory use & 1 & & & 1 & 1 & 1 & 1 & 1 & 1 & 1 & 1 \\
\hline & Structure & Standardised processes & & & & 1 & 1 & 1 & 1 & 1 & 1 & 1 & 1 \\
\hline & Management & Measurement emphasis & & & & 1 & & 1 & 1 & 1 & 1 & 1 & 1 \\
\hline & Structure & $\begin{array}{l}\text { Accountable for } \\
\text { performance improvement }\end{array}$ & & & & & 1 & 1 & 1 & 1 & 1 & 1 & 1 \\
\hline & Structure & $\begin{array}{l}\text { External benchmarking of } \\
\text { performance }\end{array}$ & & & & 1 & & 1 & 1 & 1 & 1 & 1 & 1 \\
\hline & Task & $\begin{array}{l}\text { Provided/Managed end to } \\
\text { end }\end{array}$ & & & 1 & & 1 & 1 & 1 & 1 & 1 & 1 & 1 \\
\hline & Management & $\begin{array}{l}\text { Good relationship with the } \\
\text { business }\end{array}$ & & & 1 & & 1 & 1 & 1 & 1 & 1 & 1 & 1 \\
\hline & Management & $\begin{array}{l}\text { Process \& work level } \\
\text { understanding }\end{array}$ & & & 1 & & 1 & 1 & 1 & 1 & 1 & 1 & 1 \\
\hline & Management & $\begin{array}{l}\text { Large group management } \\
\text { expertise }\end{array}$ & 1 & & & & 1 & 1 & 1 & 1 & 1 & 1 & 1 \\
\hline & Skills & Enable flexibility & & & & 1 & 1 & 1 & 1 & 1 & & 1 & 1 \\
\hline & Management & Transparency & & & & 1 & & 1 & & 1 & 1 & 1 & 1 \\
\hline & Resources & IT in situ beforehand & & & 1 & & 1 & 1 & 1 & 1 & 1 & & \\
\hline & Skills & NOT too low a skill base & & & 1 & & 1 & 1 & & 1 & 1 & 1 & 1 \\
\hline \multirow{8}{*}{$\begin{array}{l}\text { Different } \\
\text { iators } \\
\text { between } \\
\text { successf } \\
\text { ul and } \\
\text { moderate } \\
\text { or } \\
\text { limited } \\
\text { success }\end{array}$} & History & Strong centre & & & & & & & 1 & 1 & & 1 & 1 \\
\hline & Environment & Standard operating model & & & & & & & 1 & 1 & 1 & 1 & \\
\hline & Resources & $\begin{array}{l}\text { Senior management } \\
\text { commitment }\end{array}$ & 1 & & & & & 1 & 1 & 1 & 1 & 1 & 1 \\
\hline & Management & Leadership focus & & & & 1 & & & 1 & & 1 & & 1 \\
\hline & Management & $\begin{array}{l}\text { Exit path for staff into } \\
\text { business }\end{array}$ & & & & & & 1 & & 1 & 1 & 1 & \\
\hline & Structure & User pays & & 1 & & 1 & & & 1 & 1 & & 1 & \\
\hline & Task & NOT expert services & & & & & & 1 & 1 & 1 & & 1 & 1 \\
\hline & Environment & NO cost cutting backdrop & & & & & & 1 & & 1 & 1 & 1 & \\
\hline
\end{tabular}

Table 3: SSC attributes raised in interviews 


\begin{tabular}{|c|c|c|}
\hline SSC & $\begin{array}{c}\text { Perception } \\
\text { of success }\end{array}$ & Sample supporting evidence \\
\hline $\mathrm{SSC} 2$ & \multirow{5}{*}{ Successful } & $\begin{array}{l}\text { "we benchmark.. and hit or beat the benchmark in about } 80 \% \text { of cases.. have } \\
\text { people from the private sector coming to learn from us" SSC2-DCS } \\
\text { "in two and a half years we've saved \$29 million in procurement contracts } \\
\text { alone" SSC2-GMCS }\end{array}$ \\
\hline SSC4 & & $\begin{array}{l}\text { "we're at arms length.. charge on a per transaction basis largely.. we have our } \\
\text { KPIs.. once you move it out the relationship changes.. more finger pointing if } \\
\text { you do not hit them.. but we do not get too much of that discussion now" SSC4- } \\
\text { MSS }\end{array}$ \\
\hline SSC5 & & $\begin{array}{l}\text { "very visible in terms of data.. users can see how we did and how they did.. see } \\
\text { how much they are spending relative to others" SSC5-GESS } \\
\text { "we have a productivity index.. a basket of services.. and now based on this } \\
\text { index we have upped productivity } 44 \% \text { since we started" SSC5-MFS }\end{array}$ \\
\hline SSC7 & & $\begin{array}{l}\text { "We do a lot of benchmarking.. we're doing a bit of internal surveying and stuff } \\
\text { like that .. positive .. some of the organisations had } 40 \text { and } 50 \text { people doing what } \\
\text { we have six people do now" SSC7-GMSS } \\
\text { "we've won awards" SSC7-GMSS } \\
\text { "Gone from } 300 \text { people to } 80 \text { " SSC7-GMSS }\end{array}$ \\
\hline SSC10 & & $\begin{array}{l}\text { "When I first took that group on there were over } 400 \text { people, } 66 \text { sites we were } \\
\text { processing out. It is down to one site and you know, less than } 30 \text { people } \\
\text { maximum, So that is a huge reduction" SSC10-GM }\end{array}$ \\
\hline SSC1 & \multirow{3}{*}{$\begin{array}{c}\text { Moderate } \\
\text { success }\end{array}$} & $\begin{array}{l}\text { "moving in the right direction.. now put the basics in place.. a service delivery } \\
\text { platform.. metrics.. but early days yet" SSC1-MD } \\
\text { "starting to get some runs on the board.. as the volume is going up our costs are } \\
\text { not..maybe } 30 \text { cents in the dollar at the marginal end" SSC1-MD }\end{array}$ \\
\hline SSC8 & & $\begin{array}{l}\text { "on a scale of one to } 10 \text {, we're probably about three in terms of our level of } \\
\text { sophistication. I think we've got a long way to go" SSC8-GM } \\
\text { "we've got some success .. recognition of shared services . but we still have to } \\
\text { translate that into significant cost savings .. some improvements but pretty } \\
\text { marginal cuts [in costs]" SSC8-PD }\end{array}$ \\
\hline SSC9 & & $\begin{array}{l}\text { "Customer service wasn't great, perception wasn't great of shared services, and I } \\
\text { think also the service levels were down and cost was high" SSC9-MSD } \\
\text { "we started off with over } 400 \text { staff in } 1999 \text { now we've got about } 270 \text { doing more } \\
\text { work that we did originally and with less charge out back to the units.. still got a } \\
\text { way to go.. we've got some trust but moving slowly" SSC9-GM }\end{array}$ \\
\hline SSC3 & \multirow{3}{*}{$\begin{array}{l}\text { Limited } \\
\text { success }\end{array}$} & $\begin{array}{l}\text { A lot of systems where they are having difficulties- especially the HR side of it, } \\
\text { the payroll and rostering and all of those sorts of things" SSC } 3-G M \\
\text { "It has not been received well by the organisation.. the change was not done very } \\
\text { well. What we've got now is a model that probably needs a lot of customer } \\
\text { service focus and needs a restructure" SSC3-FD }\end{array}$ \\
\hline SSC6 & & $\begin{array}{l}\text { "on the horns of a dilemma.. basic thrust is whether the shared services stays or } \\
\text { we get folded back into the lines of business. And so maybe for us, the shared } \\
\text { services model failed" SSC6-GM }\end{array}$ \\
\hline SSC11 & & $\begin{array}{l}\text { "its been a slow road.. problematic.. going back } 15 \text { years .. there's a lot of } \\
\text { education" SSC11-GM } \\
\text { "one of our foundational clients pulled out .. thought they could do better } \\
\text { themselves" SSC11-GM }\end{array}$ \\
\hline
\end{tabular}

Table 4: Assessment of success of SSCs 
Task

Table 5 illustrates the range of tasks undertaken by SSCs. Common task related items that emerged from interviews are:

- All the SSCs provide transaction processing services

- All the SSCs provide, or seek to provide, multiple service lines

- Successful/Moderate success SSCs are more likely to manage a process end-to-end but not necessarily to provide it all

- Expert services are less likely to be provided by successful SSCs

\begin{tabular}{|c|c|}
\hline & Shared service operations \\
\hline Transaction & Payroll \\
\hline processing & Cash management \\
\hline & Billing \\
\hline & Accounts Payable \\
\hline & Accounts Receivable \\
\hline & Procurement \\
\hline & Recruitment \\
\hline & Asset management \\
\hline & Banking \\
\hline & Cards management \\
\hline & Records Management \\
\hline & Logistics \\
\hline & Internal mail services \\
\hline & Outbound sales \\
\hline Expert services & Office services \\
\hline & Workers Compensation \\
\hline & Fleet Management \\
\hline & Insurance \\
\hline & Process Improvement \\
\hline & Accounting (financial \& management) \\
\hline & Property management \\
\hline & Reporting \\
\hline & Employee relations (performance management etc) \\
\hline & Training \\
\hline & Advisory (HR, Finance, process, project management etc) \\
\hline & Employee services \\
\hline & Debt recovery \\
\hline & General administration \\
\hline & Credit management \\
\hline & Analysis and reporting \\
\hline & IT Operations / Infrastructure \\
\hline & End user support \\
\hline & Systems development and management \\
\hline & Disaster recovery \\
\hline & Projects \\
\hline & Data Management \\
\hline & Single point of contact (internal/external) \\
\hline & Inbound/Outbound sales \\
\hline & IT Helpdesk \\
\hline
\end{tabular}

Table 5: Tasks undertaken by SSC 
Transaction processing was seen as the "genetic" core of the SSC

“we [often] know we can improve it because its transactional, its process-driven and we're good on process.” SSC2-DCS

The more successful SSCs sought to manage or own a process end-to-end

"end to end will still mean the process goes in and out of the shared service provider. So what we've got to do is be very active with [customers] to say, well, we're going to change our bed, but you've got to be active in changing your bed" SSC8-GM

In addition they saw the benefits of undertaking all of an organisation's transaction processing activities.

"in terms of transaction management, it doesn't matter if you're doing the payroll or paying bills or moving assets, the concept is make sure you've got low decision making .. basically, it's a formula, it's getting accuracy the first time, and so what we did is actually combined all the transaction areas and just called it transactional services" SSC7-GMSS

The most successful SSCs however also tended not to provide so-called expert services preferring to "stick to their knitting"

"chances are that you're going to do okay there if you keep the operation simple. If you don't add services that make things more complex and difficult to provide, such as value

adding [expert] type services" SSC7-GMSS

It was recognised though that the categorisation of activities as being transaction based - or not was not absolute but depended upon definition and perspective.

"Often difficult to define whether transaction.. you might say that recruitment is transactional .. certainly it would appear to have many transactional elements but HR people would all say no that is core and a professional service"'SSC4-MSS

\section{Strategy}

The common strategy related themes that emerged from interviews were:

- All the SSCs seek to realise economies of scale

- Successful/ Moderate success SSCs seek to improve existing processes

Economies of scale through centralisation, the removal of duplication and being better positioned to secure funds to invest in the latest technology were the most common reasons given for establishing SSCs. Associated with this was a focus by the more successful SSCs on process improvement with effort concentrated on those areas where the greatest potential was felt to lie.

"The main thrust is economy of scale” SSC4-MSS

"realisation that services [are] provided to the business from different areas and if put under one area of accountability.. avoid duplication" SSC6-GM

"the keeping up to date of systems, state of art, being aggressive, because that, in itself can save money” SSC8-PD

"If you look at that as an end to end process, looking at where the exceptions are occurring, rather than just looking at what the exceptions are saying in the billing area or the metering area, looking at it as an end to end process. Allocating resources in preventative areas, you can actually start decreasing those costs and increasing the 


\section{operational effectiveness "SSC11-GM}

\section{Structure}

The common structure related themes that emerged from interviews were:

- For Successful/ Moderate success SSCs use is compulsory

- $\quad$ Successful/ Moderate success SSCs have standardised processes

- Successful/ Moderate success SSCs are more likely to be held accountable for the delivery of performance improvements and assess their performance relative to external parties

- Successful SSCs are more likely to charge users for the services provided

For the more successful SSCs the use of shared services was mandated - optional use was seen as leading to potential problems and a dilution of the benefits achievable.

"Yeah, that's mandatory. There are a number of reasons for that. In our model what we really see is we will put structures in place to make our shared services as efficient as anybody else. So we get the pricing right, the service qualities right then you don't go anywhere else. If we can't get the price right and we can't get the service quality right then we'll shut the bloody thing down and you can go anywhere. You don't want to weaken your economies of scale and if you start picking and choosing" SSC2-DCS

However it was also agreed that even when mandated work needs to be done to demonstrate the benefits and avoid the emergence of work-arounds such as obtaining exemptions.

"Absolutely mandated .. but having said that, that is $[\mathrm{X}]$ years on but people - the reality is back on day one if you didn't want to come here you didn't.. It was a transition that I had to manage and from day one .. really be able to demonstrate that you could not go anywhere and get a better process" SSC10-GM

Standardisation to make sure that all parts of the business were following the same process was also seen as key.

"it's about standardisation and it's about being able to add value to a process. So unless you can standardise it, you can't get cost savings. "SSC8-GM

Being made accountable for delivering performance improvements - for example cost reductions was seen as focusing the SSC.

"They will say ... there's a global savings target that all areas have to meet and this is... let's just say it's one per cent or whatever is the operating base and it starts from next year." SSC10-GM

External benchmarking in order to assess performance and progress was seen as critical.

"[Members of a] benchmarking association.. So you get a lot of different machinations of what's going on, how they're structured, where they're developing, what systems they've got, how they operate their back office, what efficiencies they are looking for internally, what drives them as a business, how does their company see the benefits of their shared service operation, where are they in the maturity chain?" SSC2-DCS

The most successful SSCs also had a charging mechanism in place that formed the basis for regulating user demand, behaviour and expectations.

"work with the business to get them to improve.. and rather than hitting them with a stick, we've got a recharge model" SSC7-GMSS 
"but it became a [free good], you keep asking and asking, and we keep delivering... give them some accountability for the volume and the cost to them" SSC1-MD

\section{Management processes}

The common management related themes that emerged from interviews were:

- Successful/ Moderate success SSCs are more likely to focus on developing good relationships with their customers in the business often accompanied by Successful SSCs encouraging their staff to seek future opportunities with those customers

- Successful/ Moderate success SSCs are more likely to have an emphasis on measurement

- Successful/ Moderate success SSCs are more likely to have a transparent management style

- Successful SSCs are more likely to a focus on leadership

- Limited success SSCs are more likely to not fully understand the processes they provide or the level of work

- Limited success SSCs are more likely to not have expertise in managing large groups of employees

Good relationships with the business were generally seen as critical.

"it's important for all my managers and myself to actually put a lot of time into relationship managing.. we try to be very customer focused.. We try to treat them like a customer, as opposed to an internal part of the organisation "SSC7-GMSS

Losing employees to customers was also considered beneficial by the most successful SSCs.

"I'm happy when one of our staff gets a job elsewhere in the business - it means we gain an ally and advocate" SSC4-MSS

It was suggested that a focus on measurement enabled prior performance levels, and progress from them, to be established and demonstrated.

"our problem is twofold. A, we nor the [business] knew what it used to cost before they gave it to us. B, at this stage of the game, we are still unable to determine what the cost potentially would have been if the [areas] had continued to share work" SSC8-GM

But the need to be selective in measurement - knowing why something was being measured and how the results would be acted on - was also widely commented on.

“An industry in itself and you just don't want to create that overhead again.” SSC1-MD

Transparency was seen as key - with SSC customers and staff.

"we're very transparent with decisions that we make. All our staff know why - we can make tough decisions. We're very clear about what their role is and what they need to do and how it fits into the corporate plan" SSC9-GM

A consistent theme amongst the most successful SSCs was the importance of leadership

"his strength is leadership so he instils in the four or five people who report to him a real culture of getting your people ripe." SSC5-MFS

"a good percentage of the time is staff and coaching and mentoring and leading my guys. I spend a fair bit of time with my direct reports in a coaching role, in a mentoring role." SSC10-GM 
One of the most necessary things to have in place before moving to shared services was seen to be a good understanding of how the impacted processes work (and thus where improvements can be made) and the level of work that can be expected - otherwise the SSC will find itself in catch-up mode from the outset.

"my initial focus was clearly on understanding the work then understanding the expectations of the customer and delivering to that." SSC10-GM

It could also be problematic if the SSC did not have experience or expertise in managing large groups of employees

"do not have the capabilities in terms of managing large groups of people in support areas” SSC6-MCS

\section{Individual skills}

The common individual skill related themes that emerged from interviews were:

- Successful/ Moderate success SSCs are more likely to look for ways to increase the flexibility of their workforce

- Limited success SSCs are more likely to have a workforce with a skill base that is too low for their needs

A number of interviewees in limited success SSCs complained that the lack of flexibility in staffing arrangements within their organisations made it hard to cystallise efficiency improvements into staff and cash savings

"practically need to get union dispensation from the unions [to employ contractors] .. we do not have much flexibility” SSC11-EM

The more successful SSCs however suggested that rather than sit back and complain you needed to push to the limits of what you could actually do.

"a rough review has shown that even within all the employee frameworks that we have, there's a lot of flexibility that we're not using.. It just simply hasn't been practised. The tradition is not there. No one has put their hand out and said, I'll take the risk and start it. But we have." SSC8GM

The ability - depending upon how the SSC was structured - to develop generalists was often seen as one way of managing the peaks and troughs of demand.

"provide us with the ability to multi-skill a bit more and actually we tend to get obviously some bits of the shared services are busy at some times ... and we can tend to drag some people from the other areas" SSC7-GMSS

A number of the SSCs though appeared to be starting from a low capability base which was going to take time to overcome

"What we end up with is having people placed in the square peg in the round hole syndrome.. what they've done is they've dumped them together, not trained them in relation to customer service and what they're supposed to do. So I've got a whole lot of people that haven't been trained" SSC3GM

\section{Information technology}

The common IT related themes that emerged from interviews were:

- $\quad$ IT is a key foundation of SSCs 
- $\quad$ SSCs use a single, standard IT platform

IT, and especially an Enterprise Resource Planning system (ERP), was generally seen as underpinning shared services

"[our ERP] is fundamental, we believe, to our shared services and has made the transition to shared services much easier than it otherwise would have been if we didn't have a very good [ERP] platform to help us with that transition to a shared services.. because the modules are integrated.. process and applications feed off the same data" SSC5-GESS

"We automated - we targeted particular companies that we dealt with that were high transaction. And, we automated that transaction process, the backwards and forwards. The order, the receipt, the invoice, the payment right. So we spent a bit of money on EDI over the years and we got four of five top customers on and that knocked half of our transactions over night" SSC10-GM

As such one of the fundamentals was seen to be ensuring everyone was using the same core platform.

"Now a myriad of systems... So if you're a poor shared service provider sort of operative trying to say do payroll or accounts payable .. you can't easily move from servicing [A] to servicing [B], because the systems are different." SSC8-GM

\section{Environmental conditions}

The common environment related themes that emerged from interviews were:

- Successful/ Moderate success SSCs are more likely to operate in organisations that see shared services as an evolutionary initiative rather than one that will be fully formed and deliver results immediately

- Successful SSCs are less likely to be within organisations where there is a major emphasis on cutting costs

- Successful SSCs are more likely to have a standard operating model

Interviewees in Successful/Developing SSCs widely commented that it was important for the business to realise that immediate benefits and success would not be forthcoming - indeed that the introduction of shared services could be costly initially. The introduction of shared services was seen as an evolutionary process with the focus and approach adopted likely to change over time as the business became more knowledgeable and experienced regarding what was possible and achievable.

"often when you're doing this there's a significant upfront investment cost. You know, that won't be paid back till about two or three years because you will have to change, radically change systems. "SSC3-FD

In a number of organisations the scope of shared services is somewhat fluid with new activities coming in and some being passed back to the business - often if it is discovered that it can not effectively be decoupled. With the latter though instances were cited where even when activities were ultimately passed back the process improved capabilities of the SSC yielded benefits during the "in and out cycle"

"We've given a couple of bits and pieces back, when actually something doesn't make sense.. We just believe that in fact it's probably something that actually makes more sense to go back to the business. But some of that's only been able to be done, because in fact we've improved or automated something 
.. We've probably taken something that was a bit of a mess, tidied it up and then actually may be automated bits of it, so it didn't require a lot of hands on, and then actually been hey, you can go back and do this" SSC7-GMSS

It was also suggested that while cost savings will likely be realised by shared services the actual focus should be on improving service delivery.

"The idea of why you set up shared services and well some places say it is to reduce costs. But if you set up with that in mind you'll fail; if it's set up as a strategic decision to implement shared services one of the outcomes will be a reduction in costs and an improvement in service" SSC2DCS

"it wasn't received well by the organisation because what it meant was people were losing their jobs .. was looked on as a cost saving strategy for the organisation to downsize its administrative staff" SSC3-GM

A differentiator of successful SSCs was that they had a standard operating model across the business with little variation across products or trading partners

"operate in multiple different markets .. work in different ways.. effectively separate businesses"SSC11-GM

"we do not have the complexity or variety of some of the others .. makes life easier" SSC4-MSS

“We have a pretty standard business operating model across everything we do "SSC2-GMCS

"Out of the city it is a completely different ball game"SSC6-MCS

"The different areas have very different needs and ways of working which we have to accommodate "SSC1-MD

\section{History}

The common history related themes that emerged from interviews were:

- The majority of SSCs operate in organisations where there is an established emphasis on functions concentrating on their core business activities

- Successful SSCs are more likely to operate in organisations where a strong centre has retained significant control over operations

It was felt to be useful if the organisation had emphasised the importance of business units focusing on their core activities with managing a back office positioned as a distraction.

"what there was over the last five years, there was a process by which they started focusing on what the core competencies were .." SSC6-GM

"in business the pressure is always on other areas to do what they're meant to be doing, so if you're meant to be selling, well, increase revenue, don't worry about all your admin bits and pieces" SSC9-GM

An established ability, and willingness, of the corporate centre to impose its desire on business areas - in this case to establish shared services - was also stressed.

"historically the culture of the organisation is control, they like to have control, they're very autonomous in decision making and so they like things not to succeed ... they've always been told that if you own [an area] you're autonomous, you make the decisions, you've got the budget, you've got the resources you can manage it. "SSC3-GM 
"a lot of historic reasons that parts of the business never really were engaged with shared services .. independent units .. so it is a company wide philosophy that shared services is caught up in .. I guess you always have that sort of company history” SSC4-MSS

\section{Organisational resources}

The common resource related themes that emerged from interviews were:

- Capital investment in SSCs is required and generally perceived to be available

- Successful SSCs are more likely to have senior management commitment to shared services

- Successful/ Moderate success SSCs are more likely to have the required IT to be in situ before the SSC is established

The establishment of an SSC requires the availability and commitment of significant investment funds.

"highly dominated by the IT infrastructure, and we need a number between about six million to eight or nine million .. and we got that" SSC1-MD

"funding for the redundancies" SSC6-GM

“got allocated \$Xm to start and had to go back to get more a couple of times" SSC8-GM

Support from the top of the organisation was also seen as necessary to the effective establishment and operation of a SSC due to the degree of organisational change required but it then needed to be buttressed by performance.

"process is very strongly supported by the CEO ... there's no points to be gained from messing it up " SSC2-DCS

"you couldn't survive just on the fact that well the boss says I have to be here. You can rely on that for so long, but eventually the noise would be so loud it wouldn't survive "SSC7-GMS

A number of interviewees suggested that the greatest challenge was moving areas to a standardised ERP platform - and that rolling out shared services was relatively simple if this was in place.

"we didn't change a whole lot .. We reshuffled some of the chairs and a few chairs could then go .. the introduction of [the ERP] beforehand that was the big culture change" SSC5-MFS

\section{DISCUSSION}

The propositions are perhaps best considered together since they are in many ways the opposite sides of the same coin.

Proposition 1: There exists at least one alignment of attributes across the dimensions identified that is associated with successful shared services

Proposition 2: Deviations from that alignment will be associated with less successful shared services

The case studies suggest the answer is more complex than anticipated a priori. There appear to be three distinct blocks of attributes -those that all SSCs exhibit, those that only successful and moderate success ones have and those that only the most successful SSCs possess. It is also clear that for two of the blocks there are some attributes that all of the SSCs in the relevant categories do or do not possess. There are others though that not all of the relevant SSCs possess or that others 
from a different category also possess. This can be interpreted in two possible ways. Either not all of the attributes currently identified are necessary to determine which category of success a SSC sits in. Alternatively within each category there are varying degrees of success such that the SSC that can "tick off" the most attributes will be the most successful. Related to and leading on from this is the case of SSC9. In absolute terms SSC9 exhibits a comparable number of attributes to the successful SSCs - and in the cases of SSC5 and SSC10 more. Yet interviewees self-assessed the SSC to be a developing success. The data collected as part of the research does not allow for it to be determined why this is the case. Based upon the above discussion though it could be that one or more of the attributes that the successful SSCs display that SSC9 does not is critical to success. If this is the case it may relate to standardisation at the organisational level, for example with regard to policies and practices. All of the successful SSCs either reported the presence of a strong centre and/or a standard operating model which could be interpreted as reflecting such standardisation. SSC9 possessed neither. Alternatively - and somewhat related to the possibility of nuances in the degree of success existing - is the possibility that perceptions as to what constitutes success may vary between SSCs. In this scenario SSC9 could have a more demanding definition of success than SSC10 for example.

Returning to the specifics of the propositions it is suggested that there $i$ s one alignment of attributes that is associated with successful SSCs. With regard to deviations and their association with reductions in success it appears though that there are two distinct groupings - SSCs with moderate success and those with limited success.

Below is an attempt to summarise the characteristics required for a successful SSC in narrative form:

The SSC should be given responsibility for demonstrably reducing costs through economies of scale and process improvement of multiple transaction oriented tasks across multiple organisational functions. An organisation wide IT platform is key to realising those savings and should be put in place before the transition to shared services. Use of the SSC should be compulsory and charged for. The organisation should have a standard modus operandi, recognise the importance of focusing on core competencies and have a strong centre that is committed to shared services and willing to invest in the SSC for the long term. SSC management should understand the requirements and volume of each task, standardise them and develop a human resource base with the variety of skills and flexibility required to meet demand.

\section{CONCLUSIONS AND FUTURE RESEARCH}

The research has identified a series of attributes across the dimensions of task, environment, history, resources, strategy, structure, management, technology and individual skills that differentiate between successful, moderately successful and limited success SSCs. It is perhaps interesting that while the gestalt literature - on which the conceptualisation of alignment utilised here is largely based - suggests that multiple different, but internally coherent, combinations could be associated with success only one has been identified in this instance. If there is indeed only one combination that can deliver success this may mean that the appropriateness of shared services is much more limited than anticipated and organisations should conduct a thorough analysis before adopting them.

The research contributes to the academic literature in three principal ways. First, it helps to establish that there is merit in extending the boundaries of IS research to incorporate shared services given the central role played by technology. Further while having appropriate technology is seen as crucial by all of the SSCs studied it is also clearly not sufficient by itself for success. This supports the view that IS research needs to take account of the broader milieu if it is to contribute fully to improving 
business effectiveness. Second, the research extends use of the alignment concept from the organisational to the functional level and demonstrates the usefulness of combining consideration of the task, organisation and environment. Third, and most specifically, the research provides a framework that identifies the requirements for successful shared services.

From a practical perspective the research, and in particular Table 3, provides a checklist that can be used to determine whether a planned SSC is likely to be successful or not. The structure and detail of that checklist provides guidance beyond a basic consideration of whether an attribute is present or not. It can help organisations determine whether their current situation is likely to be readily changeable or not. Some attributes, such as the existence of a strong centre, are likely to be difficult to alter. Others though, such as having the supporting IT in situ beforehand, may be easier to address. In this case it may simply mean that instead of implementing the necessary IT in tandem with the introduction of shared services it is done first. Furthermore the specific assessments provided for the 11 SSCs studied - and differences within and between success categories provides additional insight regarding the relative importance of each dimensions and attribute. For example there is some evidence to suggest both that technology is fundamental to shared services and that deficiencies in management, structure and skills are the major shortcomings of limited success SSCs.

With regard to future research two major avenues are suggested. Firstly the concept of success needs to be examined in more detail. Here perceptions, generally by senior management directly associated with the SSC, were relied upon. It would be valuable to consider different perspectives for example of users or customers of the SSC. It would also be useful to determine if more objective measures of success can be identified since SSC9 raises the possibility that what is seen as success can vary between organisations. Secondly, given that the SSCs within a success grouping do not always score the same on every attribute, research that examines the attributes in more detail would be useful to provide organisations with a greater understanding of which are the most important.

\section{REFERENCES}

Andrews, K. R. The concept of corporate strategy Irwin, Homewood, 1971.

Benbasat, I., Goldstein, D. K., and Mead, M. " The case study research strategy in studies of information systems," MIS Quarterly (11:3) 1987, pp 369-386.

Bergeron, B. Essentials of shared services Wiley, Hoboken, 2003.

Borman, M. "Applying Multiple Perspectives to the BPO Decision: A Case Study of Call Centres in Australia," Journal of Information Technology (21:2) 2006, pp 99-115.

Cecil, R. "Shared services: Moving beyond success," Strategic Finance (81:10) 2000, pp 64-68.

Chan, Y. E., Huff, S. L., Barclay, D. W., and Copeland, D. G. "Business strategic orientation, information systems strategic orientation, and strategic alignment," Information Systems Research (8:2) 1997, pp 125-150.

Chan, Y. E., and Reich, B. H. "IT alignment: What have we learned?," Journal of Information Technology (22:4) 2007, pp 297-315.

Chandler, A. D. Strategy and structure: Chapters in the history of the American Industrial Enterprise MIT Press, Cambridge, 1962.

Child, J. "Managerial and organization factors associated with company performance - Part II, A contingency analysis," Journal of Management Studies (12:1) 1975, pp 12-27.

Davis, L. E., Canter, R. R., and Hoffman, J. "Current job design criteria," Journal of Industrial Engineering (6:2) 1955, pp 5-8, 21-23. 
DeLone, W., and McLean, E. "Information Systems success: The quest for the dependent variable," Information Systems Research (3:1) 1992, pp 60-95.

Dibbern, J., Goles, T., Hirschheim, R., and Jayatilaka, B. "Information systems outsourcing: A survey and analysis of the literature," Database (35:4) 2004, pp 6-102.

Domberger, S., Fernandez, P., and Fiebeg, D. "Modelling the price, performance and contract characteristics of IT outsourcing," Journal of Information Technology (15:2) 2000, pp 107118.

Drazin, R., and Van De Ven, A. H. "Alternative Forms of Fit in Contingency Theory," Administrative Science Quarterly (30:4) 1985, pp 514-539.

Dunphy, D., and Griffiths, A. The sustainable corporation: Organizational renewal in Australia Allen and Unwin, Sydney, 1998.

Etzioni, A. "Organizational Control and Structure," in: Handbook of Organizations, J.G. March (ed.), Rand McNally, Chicago, 1965, pp. 650-677.

Farbey, B., Land, F., and Targett, D. "Moving IS evaluation forward: Learning themes and research issues," Journal of Strategic Information Systems (8:2) 1999, pp 189-207.

Faulkner, D. Strategy: Critical perspectives on business and management Routledge, Oxford, 2002.

Firestone, W. A., and Herriott, R. E. "The Formalization of Qualitative Research: An Adaptation of "Soft" Science to the Policy World," in: Multisite Qualitative Policy Research in Education: A Study of Recent Federal Experience, W.A. Firestone and R.E. Herriott (eds.), Authors, Report No. NIE-400-80-0019 Concord, 1982.

Galbraith, J. R. Designing Organizations: An Executive Guide to Strategy, Structure and Process Jossey-Bass, San Francisco, 2002.

Hagel III, J., and Brown, J. S. "Your next IT strategy," Harvard Business Review (79:9) 2001, pp $105-113$.

Hall, R. H. "Intraorganizational structural variation: Application of the bureaucratic model," Administrative Science Quarterly (7:3) 1962, pp 295-308.

Hannan, M., and Freeman, J. "The population Ecology of Organizations," American Journal of Sociology (82:5) 1977, pp 929-964.

Hathaway, R. S. "Assumptions underlying quantitative and qualitative research: Implications for institutional research," Research in Higher Education (36:5) 1995, pp 535-562.

Henderson, J., and Venkatraman, N. "Strategic alignment: Leveraging information technology for transforming organizations," IBM Systems Journal (32:1) 1993, pp 4-16.

Herriott, R. E., and Firestone, W. A. "Multisite qualitative policy research: Optimizing description and generalizability," Educational Researcher (12:2) 1983, pp 14-19.

Hooper, V., Huff, S., and Thirkell, P. "IS-Marketing alignment: Its impact on marketing performance and on business performance," European Conference on Information Systems, St Gallen, Switzerland, 2007.

Hrebiniak, L. G. "The organization and environment research program: Overview and critique," in: Perspectives on Organization and Behavior, A.H. Van De Ven and W.F. Joyce (eds.), Wiley, New York, 1981, pp. 338-345.

Janssen, M., and Joha, A. "Motives for Establishing Shared Service Centres in Public Administrations," International Journal of Information Management (26:2) 2006, pp 102115 .

Katz, D., and Kahn, R. The Social Psychology of Organizations Wiley, New York, 1966. 
Kern, T. "The Gestalt of an Information Technology Outsourcing Relationship: An Exploratory Analysis," International Conference on Information Systems, Atlanta, Georgia, 1997.

Kerr, D. V., and Houghton, L. "Just in time or Just in case: A case study on the impact of context in ERP implementations," Australasian Journal of Information Systems (16:2) 2010.

Kerr, P. "WA junks pay system, Oracle," in: Australian Financial Review, Fairfax, Sydney, 2011, p. 9.

Kreklow, S. R., and Kinney, A. S. "The effective organization of administration functions through shared services," Government Finance Review (23:3) 2007, pp 61-62.

Leavitt, H. J. "Applied organizational change in industry: structural, technological and humanistic approaches," in: Handbook of organizations, M. J.G. (ed.), Rand McNally, Chicago, 1965, pp. 1144-1170.

Lee, J., Miranda, S. M., and Y, K. "IT Outsourcing Strategies: Universalistic, Contingency and Configurational Explanations of Success," Information Systems Research (15:2) 2004, pp $110-131$

Leonardi, P. M., and Bailey, D. E. "Transformation Technologies and the Creation of New Work Practices: Making Implicit Knowledge Explicit in Task-based Offshoring," MIS Quarterly (32:2) 2008, pp 411-436.

Longwood, J., and Harris, R. G. "Leverage Business Process Outsourcing Lessons to Build a Successful Shared Business Service Organisation," G00144283, Gartner, Stamford.

Luftman, J., Lewis, P. R., and S.H., O. "Transforming the enterprise: The alignment of business and information technology strategies," IBM Systems Journal (32:1) 1993, pp 198-221.

MacGregor, R. C., Hyland, P. N., and Harvie, C. "Do Organisational Characteristics Explain The Differences Between Drivers of ICT Adoption in Rural and Urban General Practices in Australia," Australasian Journal of Information Systems (16:1) 2009.

March, J. G. (ed.) Handbook of Organizations Rand McNally, Chicago, 1965.

Miles, M. B., and Huberman, A. M. Qualitative Data Analysis: An Expanded Sourcebook, (2nd ed.) Sage, Thousand Oaks, 1994.

Miller, D. "Evolution and revolution: A quantum view of structural change in organisations," Journal of Management Studies (19:2) 1982, pp 131-151.

Mintzberg, H. The structuring of organizations Prentice-Hall, Upper Saddle River, 1998.

Mintzberg, H., and Lampel, J. "Reflecting on the strategy process," Sloan Management Review (40:3) 1999.

Nadler, D. A., and Tushman, M. L. Competing by design Oxford University Press, New York, 1997.

Pollalis, Y. A. "Patterns of Co-alignment in Information Intensive Organizations: Business Performance Through Integration Strategies," International Journal of Information Management (23:6) 2003, pp 469-492.

Porter, M. Competitive Advantage: Creating and Sustaining Superior Performance Free Press, New York, 1985.

Porter, M. "Towards a dynamic theory of strategy," Strategic Management Journal (12:Winter) 1991, pp 96-117.

Quinn, B., Cooke, R., and Kris, A. Shared Services: Mining for Corporate Gold Prentice-Hall, Harlow, 2000.

Rayner, R. "Reuters' finance and accounting shared services drive global efficiency," Gartner, Stamford. 
Roseman, M., Recker, J., Indulska, M., and Green, P. "Business Process Modelling - A Comparative Analysis," Journal of the Association for Information Systems (10:4) 2009, pp 333-363.

Schulman, D. S., Dunleavy, J. R., Harmer, M. J., and Lusk, J. S. "Shared Services: adding value to the business Units," Wiley, New York, 1999.

Schulz, V., and Brenner, W. "Characteristics of shared service centers," Transforming Government: People, Process and Policy (4:3) 2010, pp 210-219.

Scott-Morton, M. S. The Corporation of the 1990s Oxford University Press, New York, 1991.

Seddon, P. B., Staples, S., Patnayakuni, R., and Bowtell, M. "Dimensions of information systems success," Communications of the AIS (2:20) 1999, pp 1-32.

Shah, B. "Shared services: Is it for you," Industrial Management (Sept-Oct:4-8) 1998.

Stockdale, R., and Standing, C. "An interpretive approach to evaluating information systems: A content, context, process framework," European Journal of Operational Research (173:3) 2006, pp 1090-1102.

Strauss, A., and Corbin, J. Basics of Qualitative Research: Grounded Theory Procedures and Techniques Sage, Newbury Park, 1990.

Taylor, F. W. Principles of scientific management Harper and Row, New York, 1911.

Ulbrich, F. "Improving Shared Service Implementation: Adopting Lessons from the BPR Movement," Business Process Management Journal (12:2) 2006, pp 191-205.

Van de Ven, A. H., and Delbecq, A. L. "A task contingent model of work-unit structure," Administrative Science Quarterly (19:2) 1974, pp 183-197.

Venkatraman, M. "The concept of fit in strategy research: Toward verbal and statistical correspondence," Academy of Management Review (14:3) 1989, pp 423-444.

Venkatraman, N. "Strategic orientation of business enterprises: The construct and its measurement," University of Pittsburgh, Pittsburgh, 1985.

Walsham, G. Interpreting Information Systems in Organizations Wiley, Chichester, 1993.

Weber, M. Economy and Society University of California Press, Berkeley, 1978.

Weill, P., Broadbent, M., and Butler, C. "Exploring how firms view IT infrastructure," Melbourne Business School.

White, R. E. "Generic business strategies, organizational context and performance," Strategic Management Journal (7:3) 1986, pp 217-231.

Willcocks, L. P., Lacity, M., and Cullen, S. "Outsourcing: Fifteen Years of Learning," in: The Oxford Handbook of Information and Communication Technologies, R. Mansell, C. Averou, D. Quah and R. Silverstone (eds.), Oxford University Press, Oxford, 2007.

Yin, R. Changing Urban Bureaucracies Lexington Books, Lexington, 1979.

Yin, R. "The Case Study Crisis: Some Answers," Administrative Science Quarterly (26) 1981, pp 58-65. 


\section{APPENDIX 1: SHARED SERVICES CASE STUDY PROTOCOL}

Service - Follow ups regarding effectiveness

What activities are provided by the SSC

What characteristics make an activity appropriate for shared services

Shared services centre design - Follow ups regarding effectiveness

\section{Strategy}

What are the principal goals of the SSC

How are these goals to be realised - in principal enablers

\section{Structure}

How will work be coordinated to achieve the desired results - specific practices

What performance measures/checks are in place

\section{Management processes}

What are the principal management foci (direction and control) of the SSC

What are the critical skills managers require

\section{Individual skills}

What types (and level) of skills are required of employees

Were such skilled employees already available within the organisation

\section{Information technology [IT]}

What IT is used by the SSC

How important to the SSC is IT

Organisational context - Follow ups regarding effectiveness [and changes since establishment]

\section{Organisational resources}

What assets (employees, technology, capital and information) were important to the establishment of the SSC

Were all these assets sufficiently available

\section{History}

How were activities organised before the SSC

Did this arrangement impact on the SSC

\section{Environmental conditions}

Was anything occurring in the broader organisation that impacted the SSC (eg initiatives, leadership changes, regulation, union activity, competition)

\section{Shared services success}

How successful is the SSC

On what do you base that assessment 
APPENDIX 2: SUMMARY DATA DISPLAY TABLE

\begin{tabular}{|c|c|c|c|c|c|}
\hline & $\begin{array}{l}\text { Performance } \\
\text { perceptions }\end{array}$ & Task & Strategy & Structure & Management processes \\
\hline SSC1 & - Moderate & $\begin{array}{l}\text { - Broad range of services } \\
\text { - Transaction and expert } \\
\text { - Partial process }\end{array}$ & $\begin{array}{l}\text { Scale } \\
\text { - Process improvement } \\
\text { - Effective use of capital } \\
\text { - Independent company structure }\end{array}$ & $\begin{array}{l}\text { - Journey towards standard } \\
\text { - Compulsory } \\
\text { - Price charging } \\
\text { - Benchmarking in progress }\end{array}$ & $\begin{array}{l}\text { - Leadership } \\
\text { - Service delivery framework } \\
\text { - Measurement/analytical focus } \\
\text { Client education } \\
\text { - Manage suppliers } \\
\text {. Transparency }\end{array}$ \\
\hline SSC2 & - Successful & $\begin{array}{l}\text { - Broad range of services } \\
\text { - Transaction focus } \\
\text { - End to end focus but not all within } \\
\text { shared services }\end{array}$ & $\begin{array}{l}\text { - Scale } \\
\text { - Process improvement } \\
\text { - Automate }\end{array}$ & \begin{tabular}{|l|} 
- Standard \\
- Compulsory \\
- Corporate keeps savings \\
- User pays (cost recovery) \\
- Benchmark \\
Demonstrate value for funding \\
\end{tabular} & $\begin{array}{l}\text { - Business benefits focused } \\
\text { Leadership } \\
\text { - Business relationships } \\
\text { - Measurement emphasis } \\
\text { - Different skills at different times }\end{array}$ \\
\hline SSC3 & - Limited & $\begin{array}{l}\text { - Broad range of services } \\
\text { - Transaction and expert } \\
\text { - Partial process } \\
\text { - Orphan activities }\end{array}$ & $\begin{array}{l}- \text { Scale }- \text { efficiencies with simple } \\
\text { process focus } \\
\text { - Level of service (reduce) }\end{array}$ & $\begin{array}{l}\text { - Custom } \\
\text { - Compulsory }\end{array}$ & $\begin{array}{l}\text { - Policies and procedures focus } \\
\text { - Education }\end{array}$ \\
\hline SSC4 & - Successful & $\begin{array}{l}\text { - Broad range of services } \\
\text { - Transaction } \\
\text { - End-to-end process }\end{array}$ & $\begin{array}{l}- \text { Scale } \\
\text { - Process improvement (and } \\
\text { consistency) } \\
\text { - Core business focus } \\
\text { - Automation } \\
\text { - Measurement } \\
\end{array}$ & $\begin{array}{l}\text { - Standard } \\
\text { - Compulsory } \\
\text { - Price charging } \\
\text { - Benchmark } \\
\text { - Put under pressure (cost) }\end{array}$ & $\begin{array}{l}\text { - Business relationships } \\
\text { - Measurement (appropriate) } \\
\text { - Maintaining alignment across services } \\
\text { - Transparency } \\
\text { - Train staff for the business }\end{array}$ \\
\hline SSC6 & - Limited & $\begin{array}{l}\text { - Broad range of services } \\
\text { - Transaction and expert } \\
\text { - Partial process }\end{array}$ & $\begin{array}{l}\text { - Scale } \\
\text { - Enable core business focus }\end{array}$ & $\begin{array}{l}\text { - Custom } \\
\text { Optional use - cherry pick services } \\
\text { - Price charging }\end{array}$ & $\begin{array}{l}\text { - Education } \\
\text { Lack large scale HR management expertise } \\
\text { Lack understanding of process \& work levels }\end{array}$ \\
\hline
\end{tabular}




\begin{tabular}{|c|c|c|c|c|c|}
\hline SSC7 & - Successful & $\begin{array}{l}\text { - Broad range of services } \\
\text { - Transaction } \\
\text { - Own the process }\end{array}$ & $\begin{array}{l}\text { - Scale } \\
\text { - Process improvement } \\
\text { - Standard template for expansion } \\
\text { - Control } \\
\text { - Risk management }\end{array}$ & $\begin{array}{l}\text { - Standard } \\
\text { - Compulsory } \\
\text { - Corporate keeps savings - but user } \\
\text { incentive } \\
\text { - User pays (cost recovery) } \\
\text { - Benchmark } \\
\text { - Demonstrate value for funding }\end{array}$ & $\begin{array}{l}\text { - Business relationships } \\
\text { - Transparency } \\
\text { - Measurement emphasis } \\
\text { - Train staff for the business }\end{array}$ \\
\hline SSC8 & - Moderate & $\begin{array}{l}\text { - Broad range of services } \\
\text { - Transaction } \\
\text { - Expert } \\
\text { - End to end focus but not all within } \\
\text { shared services }\end{array}$ & $\begin{array}{l}\text { - Scale } \\
\text { - Process improvement }\end{array}$ & $\begin{array}{l}\text { - Journey towards standard } \\
\text { - Compulsory } \\
\text { - Intro of accountability } \\
\text { - Performance assessed }\end{array}$ & $\begin{array}{l}\text { - Business relationships } \\
\text { - Customer rather than administrative orientation }\end{array}$ \\
\hline SSC10 & - Successful & $\begin{array}{l}\text { - Broad range of services } \\
\text { - Transaction focus } \\
\text { - End-to-end process } \\
\text { - Own the process }\end{array}$ & $\begin{array}{l}\text { - Centralisation - Scale } \\
\text { - Process improvement } \\
\text { - Reduce labour costs }\end{array}$ & $\begin{array}{l}\text { - Standard } \\
\text { - Compulsory (over time) } \\
\text { - Corporate overhead } \\
\text { - Benchmark } \\
\text { - Put under pressure (cost) }\end{array}$ & $\begin{array}{l}\text { - Business relationships - sell contribution } \\
\text { - Measurement determines focus } \\
\text { - Leadership (mentoring) } \\
\text { - Transparency }\end{array}$ \\
\hline
\end{tabular}


Part II Data display summary of the shared service centre dimensions

\begin{tabular}{|c|c|c|c|c|c|}
\hline & Individual skills & Information technology & Environmental conditions & History & Organisational resources \\
\hline SSC1 & $\begin{array}{l}\text { - Low skill base } \\
\text { - Flexible - can offload } \\
\text { excess staff } \\
\text { - Process mapping } \\
\text { - Workforce planning - } \\
\text { multiskill / systems training }\end{array}$ & $\begin{array}{l}\text { - Towards standard } \\
\text { - Enabler }\end{array}$ & $\begin{array}{l}\text { - Cost cutting focus } \\
\text { - Structural change } \\
\text { - Varied client needs }\end{array}$ & - Mandated & $\begin{array}{l}\text { - Seed funded } \\
\text { - Self fund beyond }\end{array}$ \\
\hline SSC2 & $\begin{array}{l}\text { - Low skill base } \\
\text { - Manage to enable } \\
\text { flexibility } \\
\text { - Share ideas - communicate } \\
\text { - Self service }\end{array}$ & $\begin{array}{l}\text { - Standard } \\
\text { - Enabler }\end{array}$ & $\begin{array}{l}\text { - Cost cutting focus } \\
\text { - Impetus } \\
\text { - Standard operating model }\end{array}$ & $\begin{array}{l}\text { - Project success } \\
\text { - Strong centre } \\
\text { - Core business focus }\end{array}$ & $\begin{array}{l}\text { - Business case } \\
\text { - Largely in situ } \\
\text { beforehand } \\
\text { - Management focus }\end{array}$ \\
\hline SSC3 & $\begin{array}{l}\text { - Low skill base } \\
\text { - Inflexible } \\
\text { - Process mapping } \\
\text { - Need to upskill / build } \\
\text { expertise }\end{array}$ & $\begin{array}{l}\text { - Standard } \\
\text { - Enabler } \\
\text { - Modify system to processes }\end{array}$ & \begin{tabular}{|l|} 
- Cost cutting focus \\
- Expect immediate results
\end{tabular} & \begin{tabular}{|l} 
- Autonomy \\
- Big bang approach
\end{tabular} & $\begin{array}{l}\text { - Short term focus } \\
\text { - Allocated - limited } \\
\text { - Management support } \\
\text { - Nobody wants to work in } \\
\text { SS }\end{array}$ \\
\hline SSC4 & $\begin{array}{l}- \text { Manage to enable } \\
\text { flexibility } \\
\text { Workforce planning and } \\
\text { career paths (internal) }\end{array}$ & $\begin{array}{l}\text { - Standard } \\
\text { - Enabler - but can restrict } \\
\text { - Primarily outsourced }\end{array}$ & $\begin{array}{l}\text { - Growth - positive atmosphere } \\
\text { - Simple business (not complex) }\end{array}$ & $\begin{array}{l}\text { - Strong centre } \\
\text { - Greenfield } \\
\text { - Core business focus }\end{array}$ & $\begin{array}{l}\text { - } \text { Business case } \\
\text { - Put under pressure (cost) } \\
\text { - Largely in situ } \\
\text { beforehand } \\
\text { - Management focus }\end{array}$ \\
\hline $\operatorname{SSC5}$ & - Self service & $\begin{array}{l}\text { - Solution } \\
\text { - Standard }\end{array}$ & - Standard operating model & - Autonomy & $\begin{array}{l}\text { - Allocated - sufficient } \\
\text { - Largely in situ } \\
\text { beforehand } \\
\text { - Management focus }\end{array}$ \\
\hline SSC6 & $\begin{array}{l}- \text { Low skill base } \\
\text { - Inflexible }\end{array}$ & $\begin{array}{l}\text { - Varied } \\
\text { - Enabler }\end{array}$ & \begin{tabular}{|l|} 
- Cost cutting focus \\
- Structural change \\
- Expect immediate results
\end{tabular} & $\begin{array}{l}\text { - Outside the core } \\
\text { - Autonomy } \\
\text { - Core business focus }\end{array}$ & $\begin{array}{l}\text { - Limited } \\
\text { - Allocated - sufficient }\end{array}$ \\
\hline
\end{tabular}




\begin{tabular}{|c|c|c|c|c|c|}
\hline SSC7 & $\begin{array}{l}\text { - Green field - select skills } \\
\text { required } \\
\text { - Multiskill - flexibility }\end{array}$ & $\begin{array}{l}\text { - Solution - but not IT for } \\
\text { IT's sake } \\
\text { - Standard }\end{array}$ & $\begin{array}{l}\text { - Expansion (takeover) } \\
\text { - Growth - positive atmosphere } \\
\text { - Lack of interest } \\
\text { - One way of doing things }\end{array}$ & $\begin{array}{l}\text { - Strong centre } \\
\text { - Core business focus }\end{array}$ & $\begin{array}{l}\text { - Business case } \\
\text { - Generate working capital } \\
\text { - Management focus }\end{array}$ \\
\hline SSC8 & \begin{tabular}{|l} 
- Shortage \\
- Innovation for flexibility \\
- Work group
\end{tabular} & $\begin{array}{l}\text { - Solution } \\
\text { - Standard }\end{array}$ & $\begin{array}{l}\text { - Mandated } \\
\text { - Structural change } \\
\text { - Cost cutting focus }\end{array}$ & $\begin{array}{l}\text { - Autonomy } \\
\text { - Core business focus }\end{array}$ & $\begin{array}{l}\text { - Allocated - sufficient } \\
\text { - Largely in situ } \\
\text { beforehand }\end{array}$ \\
\hline SSC9 & $\begin{array}{l}\text { - Process mapping and } \\
\text { measurement } \\
\text { - Well defined roles } \\
\text { - Multiskill - flexibility }\end{array}$ & $\begin{array}{l}\text { - Enabler } \\
\text { - Standard }\end{array}$ & $\begin{array}{l}\text { Have to accommodate } \\
\text { different ways of working }\end{array}$ & $\begin{array}{l}\text { - Autonomy } \\
\text { - Core business focus }\end{array}$ & $\begin{array}{l}\text { - Business case } \\
\text { - Largely in situ } \\
\text { beforehand } \\
\text { - Management interest }\end{array}$ \\
\hline SSC10 & $\begin{array}{l}- \text { Manage to enable } \\
\text { flexibility }\end{array}$ & \begin{tabular}{|l|} 
- Standard \\
- Enabler/Solution - \\
workflow/automation
\end{tabular} & \begin{tabular}{|l} 
- Cost cutting focus \\
- Politics
\end{tabular} & $\begin{array}{l}\text { - Strong centre } \\
\text { - Core business focus }\end{array}$ & $\begin{array}{l}\text { - Limited capital } \\
\text { expenditure } \\
\text { - Allocation but business } \\
\text { case possible } \\
\text {. Management focus }\end{array}$ \\
\hline SSC11 & - Inflexible & $\begin{array}{l}\text { - Standard } \\
\text { - Solution } \\
\text { - Modify system to processes }\end{array}$ & $\begin{array}{l}\text { - Expansion (organic) } \\
\text { - Cost cutting focus } \\
\text { - Structural change } \\
\text { - Expect immediate results }\end{array}$ & \begin{tabular}{|l} 
- Soft restructure \\
- Autonomy \\
- Core business focus
\end{tabular} & $\begin{array}{l}\text { - Constrained }- \text { allocated } \\
\text { - Largely in situ } \\
\text { beforehand }\end{array}$ \\
\hline
\end{tabular}

